\title{
Spoken German Step by Step: Research, Roots and Redirections
}

\section{Louise Jansen (Australian National University)}

How did researchers come to develop an interest in studying classroom learners of German? What do the stages in the acquisition of German look like and how are they explained? Do we know enough about how learners learn in order to apply our knowledge of this in teaching? These are some of the themes in Boss and Diehl's paper (this volume) on the teaching of grammar, which I would like to take up and explore further.

First, I will briefly sketch the historical strands in research which have led to the study of how classroom learners acquire German. I will then give an overview of studies conducted on spontaneous speech - rather than on written samples as in Diehl et al (2000) - and explain in greater detail the stages of acquisition in German word order, which so far has been the focus of studies on oral data. In conclusion I will suggest some directions for further research as well as for applications to teaching.

The exploration of classroom learners' acquisition of German goes back to the seventies, when research in Germany started to focus on the sociopolitical and linguistic situation of migrant workers who had come to Germany from the poorest regions of southern Europe (including Italy, Spain and Portugal) with little formal education and no prior knowledge of German. Upon their arrival there was an immediate need to communicate - however rudimentarily - in the language of their host country. This is essentially how they acquired German. Researchers interested in language and communication started to explore whether a pidgin variety of German was emerging, whether and why German speakers spoke differently to the migrant workers than to their fellow native speakers and how the migrants managed to learn the language without the benefit of instruction. It is the last strand of research which eventually led to investigations of classroom learning.

As there was no previous research into the acquisition of German as a second language, researchers seeking to investigate how migrant workers 
acquire the language (eg: Clahsen Meisel and Pienemann 1983; Heidelberger Forschungsprojekt 1979) took their lead mostly from American studies on the acquisition of English as a first and second language. These studies had found that all learners progressed through a sequence of stages which were basically the same, although there were some differences between first and second language learners. In addition, it was found that second language learners differed according on their degree of social distance from the target language culture: those who were socially distant did not get very far in their language learning, even after many years, and the language they spoke was much more simplified than that of other learners (see e.g. Schumann 1978).

Research into migrant workers' acquisition of German thus was guided by two hypotheses. One was that the acquisition would progress through stages which are the same for all learners. If this was found to be the case, the stages of acquisition for German would need to be established. The second hypothesis was that the learners' language would vary depending on the degree of their integration into German society. Both hypotheses were confirmed: specific stages were found in the acquisition of German word order and the migrant workers spoke more simplified forms of German the more they were isolated from German society. However, it was primarily the first hypothesis which influenced research into classroom learning.

Why do learners progress through stages? And why are these the same for all learners? Answers to these questions were sought in the field of psycholinguistics. It was argued that due to limitations in speech processing resources learners were not able to communicate proficiently in a new language from the start; instead they unconsciously reduced the complexities of the target language to simpler, manageable components, which build onto one another. The sequence of stages observed reflected the increasing complexity of language features, but did not explain why this was so. For example, why were learners able to place a past participle in clause-final position ("Satzklammer") before they could place a verb in second position ("Inversion")? An explanation proposed was that moving elements into a salient (for instance sentence-final) position required 
fewer processing resources, and therefore the corresponding structures were acquired earlier than those involving movement to a sentence-internal non-salient position (Clahsen 1984).

As the explanations were based on limitations in human speech processing resources (which are the same for all learners) and how these interact with the structure of a specific target language, it was hypothesised that all learners of German needed to progress through the same stages and that teaching would not be able to alter this. An initial study testing this hypothesis was carried out in Germany with the children of migrant workers. When they were experimentally taught a stage for which they were not ready - requiring them to skip a stage - this had at best no, and possibly a negative effect on their progress in acquiring German. On the other hand learners who were considered ready (that is, they had reached the stage immediately preceding the one taught) benefited from the teaching. These results led Pienemann to formulate his "Teachability Hypothesis" which holds that teaching will only be effective if learners are ready (Pienemann 1984).

Further research on the influence of instruction on stages of acquisition in German took a somewhat different direction, moving from experimental to observational studies in existing classroom settings. Most of these studies were conducted outside Germany - primarily in Australia - in settings where the learners' exposure to the language was largely restricted to the input they received in the classroom. Instead of focusing on children, these studies investigated the acquisition of German by university students (e.g. Pienemann 1984; Ellis 1989; Boss 1996; Jansen 2004). Furthermore, the learners' first language background was English rather than a Romance language, as had been the case for the migrant workers and their children. Despite the differences in age, language background and type of exposure to German between the two learner groups, it was found that the Anglophone students followed the same stages and in the same sequence as the migrant workers and their children had done. Some of the later studies also compared the learners' actual learning steps with what they had been taught according to the course programme and 
learners can identify constituents regardless of their position in the sentence, they can now move them into other positions and these no longer need to be salient.

\section{STEP 5: SCL: The learners can apply different rules of word order in main and subordinate clauses.}

Example: Wo hat sie das gelernt? > Ich weiß, wo sie das gelernt hat.

The learners have acquired the distinction between subordinate and main clauses and can now apply different rules depending on the type of clause. Thus they now have control over complex sentence structures.

To date, most studies on stages of acquisition in German as a foreign language have been conducted with the theoretical framework and research methodology used in the earlier migrant worker studies. Thus they have investigated the acquisition of word order as evident in the learners' spontaneous oral production of German. This involves audio-recording the subjects' conversations (usually with a native speaker of German) and transcribing these before analysis can begin. This time-consuming methodology is necessary because the theory underpinning the research is based on speech processing (cf. Pienemann 1998). Testing the theory furthermore requires detailed analyses of individual learners, rather than groups of learners. Moreover, fairly large speech samples (around 30 minutes for each learner) are needed to provide reasonably dependable evidence for whether or not the learner has required a certain word order rule.

These theoretical and methodological demands preclude longitudinal studies of individual learners in large numbers. However, because the stages are strictly ordered it is possible to study larger numbers of individual learners using only one sample from each of them. The stage of acquisition of each learner can be determined by studying which word order rules are evident in the sample and which are not. If care is taken to sample a wide range of learners (that is, learners with different rates of exposure to German) it is possible to plot the samples on a scale which simulates one learner's progress over time. While such cross-sectional 
studies need verification by longitudinal data they expand these in important ways, as more and a wider variety of learners can be studied in less time. In terms of reliability it is encouraging that, so far, few discrepancies have been found when findings from cross-sectional studies are compared to those from longitudinal data.

Against the background of studies based on spoken language samples, the decision by the researchers involved in the DiGS (Deutsch in Genfer Schulen) project (Diehl et al. 2000; cf. Boss and Diehl this volume) to take a more descriptive approach and use written rather than oral data has had a liberating effect. The descriptive orientation made it possible to include, but also go beyond what theories predict. Thus the project team investigated all major areas of grammar, including, but not confined to word order. Using written data eliminated the need for labour-intensive and time-consuming transcriptions, thus making it possible to study a much larger number of learners. In addition, the project's research design combines longitudinal with cross-sectional data. Its emphasis on qualitative rather than quantitative data analysis led to many new insights into how learners learn.

The stages in the acquisition of word order found by Diehl and her associates are the same as those found in the oral data, except for the last two stages which appear in reversed order, that is inversion occurs after, rather than before verb-final position in the subordinate clause. This apparent discrepancy with the findings of the earlier studies can be attributed to a number of possible causes: the nature of the data (written, not spoken), first language influence (French instead of English or one of the other Romance languages in the migrant worker studies), different acquisition criteria (mastery, rather than emergence of the rule, cf. Jansen 2000). The DiGS researchers suspect that the decisive factor is first language influence (Diehl et al., 2000:112f.). It will require further, targeted research based on oral data from Francophone learners and written data from learners from other first language backgrounds to verify this. Boss's follow-up study which applies the DiGS methodology to written data from Australian university students represents an important step in this direction (see Boss 2004 for preliminary results). 
What are the directions for future research? With respect to the acquisition of German as a whole, the grammatical areas explored to date represent only the tip of the iceberg. Many aspects of German word order are as yet unstudied, for example the placement of verb complements and adverbial phrases following the verb in second position (the "Mittelfeld"). With respect to the acquisition of morphology there are some theoretical predictions, but very little evidence on when these linguistic structures emerge in individual learners' spontaneous speech, whether or not they emerge in stages and to what degree variation between learners occurs.

On the other hand, our knowledge about the acquisition of German word order by native speakers of English and French has reached a point where the pedagogical implementation of the research results should start receiving attention, rather than the collection and analysis of further data. The DiGS project was conceived with this practical objective in mind, and plans to implement its findings are under way, as Boss and Diehl (this volume) report.

Teachers and coordinators of German courses at Australian universities might consider adopting the principles of a "pédagogie differenciée" (differentiated curriculum) as proposed by the DiGS team (Brunschwig 1999). This approach allows for keeping unlearnable structures in the early input to facilitate communication but delaying form-focused instruction until students are ready. From the teachers' point of view it involves accepting rather than censoring developmental errors in the students' spoken and written production. This does not mean that teachers should adopt a laissez-faire attitude to the mistakes their students make. Rather they should trust their experience and be wary of teaching early or intensively those grammatical areas they know to be persistent sources of error despite concerted teaching efforts. Examples of such areas are the cases, found to emerge late in the DiGS study, as well as adjective endings. Teachers should realise that it is counterproductive to increase their efforts in explaining and practising late acquired structures and in correcting errors prematurely. This will require a change in both teacher and learner attitudes, which, in the end, may turn out to be the most difficult to achieve. 


\section{References}

Ammon, U. (1991). Studienmotive und Deutschenbild australischer Deutschstudenten und studentinnen. Stuttgart: Franz Steiner.

Australian Bureau of Statistics 2001. Census of Population and Housing.

Bärenfänger, O. (2002). "Automatisierung der mündlichen L2-Produktion: Methodische Überlegungen.” In: Wolfgang. B. \& K. Vogel, (eds.), Grammatik im Fremdsprachenerwerb. Kognitive, psycholinguistische und erwerbstheoretische Perspektiven. Tübingen: Narr, 119-140.

Barko, I. (1996a). "A History of Language Education in Universities: The Background (1853-1965)." Australian Language Matters 4(1), 6-7.

Barko, I. (1996b). "A History of Language Education in Universities: The Recent Past and Today." Australian Language Matters 4(2), 6-7.

Berry, D. \& Dienes, Z. (1993). Implicit Learning. Theoretical and Empirical Issues. Hove, Hillsdale: Lawrence Erlbaum.

Boss, B. (1996). "German Grammar for Beginners - The Teachability Hypothesis and its Relevance to the Classroom." In: Arbone Sola C. \& J. Rolin-Ianziti, (eds.), Who's Afraid of Teaching Grammar? Working Papers in Language and Linguistics 1 . The University of Queensland, 93-100.

Boss, B. (2004). "Wann ich habe Freizeit, ich koche gern: Zum Erwerb der deutschen Inversion und Nebensatzwortstellung durch australische Studierende." Deutsch als Fremdsprache 41/1, 28-32.

Boss, B. \& Jansen, L. M. (2003a). "Teaching German: All for the Birds?" Babylonia N2, 30-39.

Boss, B. \& Jansen, L. M. (2003b). "Do our Students Learn what We Teach Them?" $B A B E L$ Vol. 38/2, 26-38.

Brunschwig, Graf (ed.) (1999). Recommendations DiGS Deutsch in Genfer Schulen: A propos de l'acquisition de la grammaire allemande. Geneva: Département de l'instruction publique.

Clahsen, H. (1984). "The Acquisition of German Word Order: A Test Case for Cognitive Approaches to L2 Development." In: R. Andersen (ed.), Second Language Development: A Crosslinguistic Perspective. Rowley, Mass: Newbury House, 219-42.

Clahsen, H., J. Meisel \& Pienemann, M. (1983). Deutsch als Zweitsprache: der Spracherwerb ausländischer Arbeiter. Tübingen: Narr.

Diehl, E., Christen, H., Leuenberger, S., Pelvat, I., \& Studer, T. (2000). Grammatikunterricht: Alles für der Katz? Untersuchungen zum Zweitsprachenerwerb Deutsch. Tübingen: Niemeyer. 
Diehl, E. (2002). "Grammatikunterricht - ein Thema am Schnittpunkt von Forschung und Praxis. Bericht über das Genfer Forschungsprojekt DiGS." In: Foschi, M. \& M. Hepp, (eds.), Germanistische Linguistik und Spracherwerb an italienischen Universitäten. 1334.

Djité, P. G. (1994). From Language Policy to Language Planning. An Overview of Languages Other Than English in Australian Education. National Languages and Literacy Institute of Australia.

Dörnyei, Z. \& Ottó, I. (1998). "Motivation in Action: A Process Model of L2 Motivation." Working Papers in Applied Linguistics 4: 43-69. London: Thames Valley University.

Dörnyei, Z. (1998). "Motivation in Second and Foreign Language Learning." Language Teaching 31, 117-135. Cambridge: Cambridge University Press.

Ellis, R. (1989). "Are Classroom and Naturalistic Acquisition the Same? A Study of the Classroom Acquisition of Word Order Rules." Studies in Second Language Acquisition $11,305-328$.

Ellis, R. (1994). The Study of Second Language Acquisition. Oxford: Oxford University Press.

Fernandez, S., A. Pauwels \& Clyne, M. (1994). Unlocking Australia's Language Potential: German. Canberra, National Languages and Literacy Institute of Australia.

Gardner , R.C. (1985). Social Psychology and Second Language Learning. London: Edward Arnold.

Gardner, R.C. \& MacIntyre, P.D. (1993). "A Student's Contributions to Second-Language Learning, Part II. Affective Variables." Language Teaching 266: 1-11. Cambridge: Cambridge University Press.

Harting, A. (2003). "Zur Attraktivität der Studienfächer Deutsch und Japanisch an australischen Universitäten. Ein Vergleich der Ziele, Inhalte und Methoden." Info DaF. Informationen Deutsch als Fremdsprache 30/1, 32-45.

Heidelberger Forschungsprojekt (1977). Die ungesteuerte Erlernung des Deutschen durch spanische und italienische Arbeiter. [Osnabrücker Beiträge zur Sprachtheorie, Beiheft 2].

Jansen, L. M. (2000). "Second Language Acquisition: From Theory to Data." Second Language Research 16/1, 27-43.

Jansen, L. M. (2004). "The Acquisition of German Word Order in Instructed Learners: A Cross-Sectional Study in a Larger Research Context." Language Learning (under review).

Koenig, M. (2001). "Grammatikunterricht. Von der Lehrwerk- zur Unterrichtsebene und darüber hinaus." In: Funk/Koenig (eds.), Kommunikative Fremdsprachendidaktik Theorie und Praxis. Festschrift für Gerhard Neuner zum 60. Geburtstag. Munich: Judicium, 294-311. 
Leal, B., Bettoni, C., \& Malcolm, I. (1991). Widening Our Horizons: Report of the Review of the Teaching of Modern Languages in Higher Education. Canberra: Australian Government Publishing Service.

Liddicoat, A. J., Crozet, C., Jansen, L. M., \& Schmidt, G. (1997). "The Role of Language Learning in Academic Education: An Overview." Australian Review of Applied Linguistics 20/2, 19-32.

Lund, R. (2004). "Erwerbssequenzen im Klassenraum." Deutsch als Fremdsprache 41/2, 99-103.

McNamara, T. (2001). "The History of Applied Linguistics in Australia," Australian Review of Applied Linguistics 24/1, 13-30.

Mills, A. E. (1985). "The Acquisition of German." In: Slobin (ed.) (1985). The Crosslinguistic Study of Language Acquisition. Vol. 1, 141-254. Hillsdale, N.J.: London: Lawrence Erlbaum.

Peltzer-Karpf, A. \& Zangl, R. (1998): Die Dynamik des frühen Fremdsprachenerwerbs. Tübingen: Narr.

Petit, J. (1989). "Spracherwerb durch Fehler und fehlerfreier Spracherwerb. Eine psycholinguistische und sprachtypologische Überlegung." Beiträge zur Fremdsprachenvermittlung aus dem Konstanzer Sprachlehrinstitut 19, 1-28.

Pienemann, M. (1984). "Psychological Constraints on the Teachability of Languages." Studies in Second Language Acquisition 6: 186-214. Reprinted in: C. Pfaff (ed.) (1987). First and Second Language Acquisition Processes. Rowley, Mass: Newbury House, 143-168.

Pienemann, M. (1987). "Determining the Influence of Instruction on L2 Speech Processing." Australian Review of Applied Linguistics 10: 83-113. Reprinted in: G. Kasper (ed.) (1988). Classroom research. [=AILA Review 5], 40-72.

Pienemann, M.(1989). "Is Language Teachable? Psycholinguistic Experiments and Hypotheses." Applied Linguistics 10/1, 52-79.

Pienemann, M. (1998). Language Processing and Second Language Development: Processability Theory. Amsterdam: J. Benjamins.

Schneider, B. (2004). Foreign Language Learning and Teaching in Higher Education: Closing the Gap of Learner and Teacher Perceptions. Unpublished Doctoral Dissertation, Monash University.

Schulz, G. (1976). "Zur Situation des Deutschen in Australien." In: Wierlacher, Alois et al (eds.), Jahrbuch Deutsch als Fremdsprache Vol. 2, 105-113.

Schumann, J. (1978). The Pidginization Process: a Model for Second Language Acquisition. Rowley, Mass: Newbury House.

Shekan, P. 1998. A Cognitive Approach to Language Learning. Oxford: Oxford University Press. 
Slobin, D. (1973). "Cognitive Prerequisites for the Development of Grammar." In: Ferguson, C, \& D. Slobin, (eds.), Studies of Child Language Development. New York: Appleton-Century-Crofts, 175-276.

Tisdell, M. (1997). "Zur Situation des DaF-Unterrichts an australischen Universitäten." Fremdsprachen und Hochschule 51, 93-102. 